\title{
EFISIENSI ALOKATIF PENANGANAN PASCA PANEN USAHATANI TEMBAKAU RAJANGAN MADURA
}

\section{Allocative Efficiency Of Post-Harvest Harvest Handling Tobacco Rajangan Madura}

\author{
Moh. Ramly ${ }^{1)}$, Mohammad Shoimus Sholeh ${ }^{2)}$, Rikza Alfya Anugrah Cahyaty ${ }^{3)}$ \\ ${ }^{1,2,3)}$ Dosen Universitas Islam Madura \\ email: moh.ramly.madur@gmail.com
}

\begin{abstract}
ABSTRAK
Usahatani tembakau rajangan di Pamekasan terjadi dua sistem penjualan, pertama petani menjual langsung daun tembakau masih di pohon, kedua petani melakukan pengolahan pasca panen. Permasalahan yang perlu dikaji dari efisiensi alokatif usahatani tembakau dengan sistem jual daun tembakau di pohon dan sistem pengolahan pasca panen. Mengetahui efisiensi penggunaan faktor-faktor produksi. Mengetahui pendapatan usahatani tembakau rajangan Madura. Kegiatan Penelitian akan dilakukan di Kecamatan Pademawu Kabupaten Pamekasan, Teknik analisis data yang digunakan yaitu analisis deskriptif dengan tujuan untuk menggambarkan suatu hubungan masalah dalam penelitian yang tidak dapat dijelaskan berdasarkan kuantitatif sehingga dapat memudahkan peneliti menggambarkan maupun menjelaskan data hasil penelitian. Faktor yang berpengaruh nyata serta signifikan pada produksi usahatani tembakau dengan 2 sistem yang berbeda yaitu penggunaan benih, tenaga kerja dan intensitas penyiraman, sedangkan penggunaan pestisida berpengaruh negatif. Penggunaan benih pada usahatani tembakau baik dengan sistem jual pohon maupun dengan sistem penanganan pasca panen tidak efisien, maka dari itu perlu pengurangan penggunaan benih, sedangkan untuk penggunaan tenaga kerja dan intensitas penyiraman masih belum efisien sehingga perlu penambahan tenaga kerja dan juga intensitas penyiraman khususnya bagi petani yang melakukan penanganan pasca panen tembakau.
\end{abstract}

Kata kunci : Efisiensi, Usahatani, Tembakau, Madura.

\begin{abstract}
Chopped tobacco farming in Pamekasan has two sales systems, first the farmer sells tobacco leaves directly in the tree, second the farmers do post-harvest processing. Problems that need to be assessed from the allocative efficiency of tobacco farming with the sale of tobacco leaves in trees and post-harvest processing systems. Knowing the efficient use of factors of production. Knowing Madura's tobacco farming income. The research activity will be carried out in Pademawu Subdistrict, Pamekasan Regency, the data analysis technique used is descriptive analysis used to describe conditions related to research problems. Factors that significantly and
\end{abstract}


significantly affect the production of tobacco farming both the tree selling system and the postharvest handling system are the use of seeds, labor and watering intensity, while the use of pesticides has a negative effect. The use of seeds in tobacco farming both with a tree selling system and with an inefficient post-harvest handling system, the need to reduce the use of seeds, while for the use of labor and watering intensity is still not efficient so it needs additional labor and also watering intensity, especially for farmers post-harvest tobacco handling.

Keywords: Efficiency, Farming, Tobacco, Madura.

\section{PENDAHULUAN}

Komoditas perkebunan merupakan salah satu andalan Indonesia dalam menyumbangkan devisa serta pendapatan nasional. Hal itu dilihat berdasarkan nilai komoditi ekspor hasil perkebunan Indonesia. Sejak tahun 2015 total ekspor produk hasil perkebunan mencapai 23,933 triliun. Sub sektor perkebunan memberikan kontribusi terhadap perekonomian nasional yang signifikan perkembangannya. Peningkatan kontribusi hasil perkebunan tembakau, dari tahun 2015 sampai 2017 sebesar 4.506 ton dengan nilai pada tahun 2015 sejumlah 193.790 ton menjadi 198.296 ton (Direktorat Jenderal Perkebunan, 2016).

Luas lahan untuk tanaman tembakau di wilayah Jawa Timur yaitu 106.524 ha, sedangkan khusus di wilayah Madura berkisar 53.000 ha. Tembakau Madura tersebar di empat kabupaten, dan Kabupaten yang memiliki luas areal terbesar adalah Kabupaten Pamekasan. Kabupaten Pamekasan memiliki luas lahan perkebunan tembakau yaitu 24.465 ha, dan hampir semua petani di Pamekasan melakukan usahatani tembakau.

$$
\text { Menurut Verona dan Supriyadi }
$$
(2016) mengemukakan bahwa kontribusi usahatani tembakau berturut-turut sebesar $63 \%, 73 \%, 80 \%$, sedangkan kontribusi penyerapan tenaga kerja sebesar $76 \%, 67 \%$, $59 \%$. Petani tembakau di Kabupaten Pamekasan hingga saat ini sebagian besar, belum mengalokasikan input secara optimal.
Akibatnya usahatani tembakau di Kabupaten Pamekasan belum dapat mencapai tingkat efisiensi teknis yang baik dan belum dapat mencapai hasil produktivitas yang tinggi (Fauziyah et.al, 2010).

Usahatani tembakau rajangan di Pamekasan terjadi dua sistem penjualan hasil usahatani tembakau, pertama petani menjual langsung daun tembakau masih di pohon, kedua petani melakukan pengolahan pasca panen dan dijual ke gudang tembakau. Dari permasalahan diatas, maka perlu dikaji nilai efisiensi alokatif usahatani tembakau dengan sistem jual daun tembakau di pohon dan sistem pengolahan pasca panen tembakau rajangan Madura. Tujuan diantaranya :

1. Mengetahui adanya faktor-faktor yang dapat berpengaruh terhadap produksi tembakau pada usahatani tembakau dengan sistem jual daun tembakau di pohon dan sistem pengolahan pasca panen tembakau rajangan Madura.

2. Mengetahui efisiensi penggunaan faktorfaktor produksi usahatani tembakau dengan sistem jual daun tembakau di pohon dan sistem pengolahan pasca panen tembakau rajangan Madura.

\section{METODE PENELITIAN}

\section{Lokasi Penelitian}

Kegiatan Penelitian dilakukan di
Kecamatan Pademawu Kabupaten
Pamekasan, dengan pertimbangan daerah
tersebut terdapat petani yang menjual daun
tembakauu di pohon dan petani yang


melakukan pengolahan pasca panen tembakau sendiri.

\section{Alur Penelitian} Gambar 1.

Alur penelitian sebagaimana pada

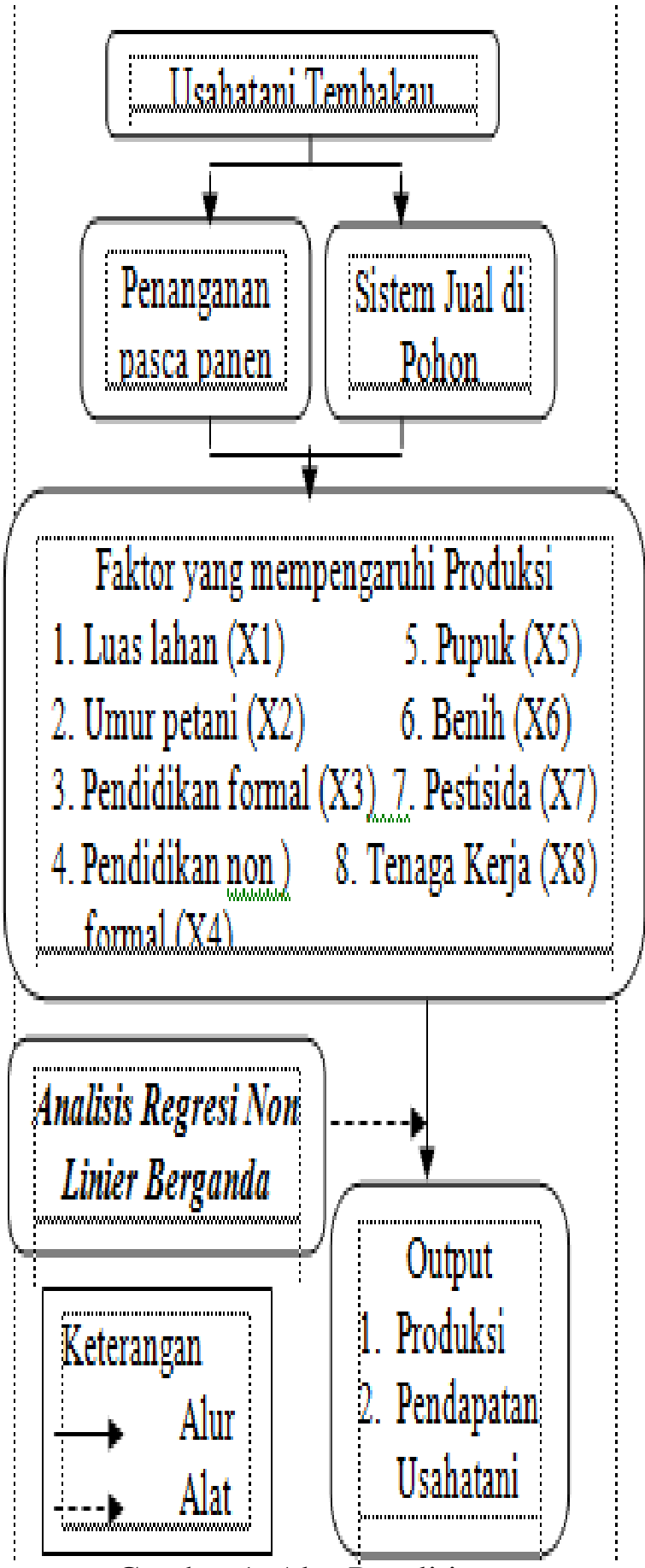

Gambar 1. Alur Penelitian
Pengumpulan Data

Metode pengumpulan data sebagaimana pada Gambar 2.

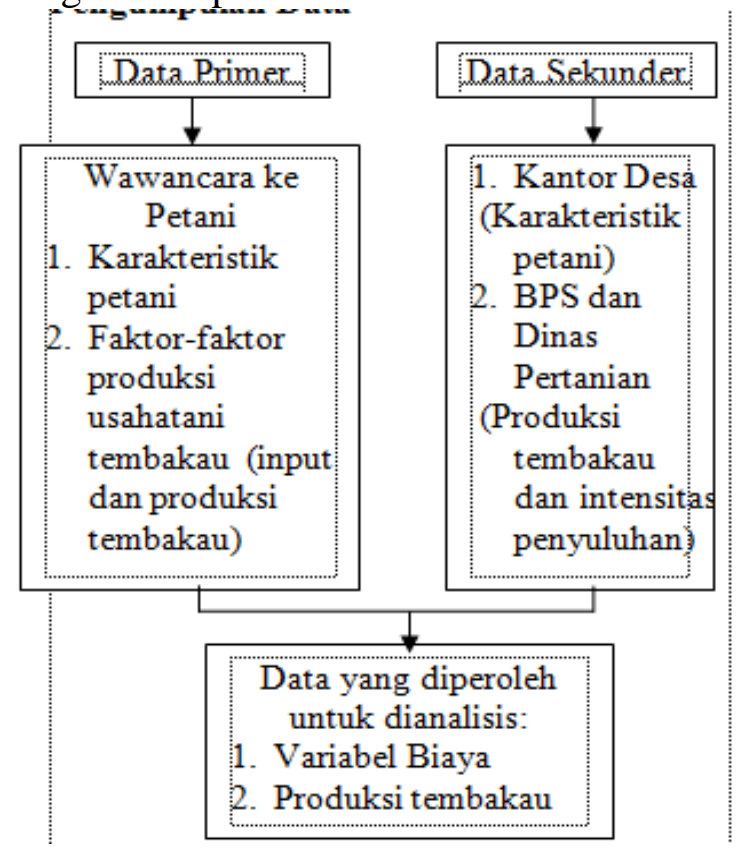

Gambar 2. Metode Pengumpulan Data

\section{Analisa Data}

Teknik analisis data yang digunakan yaitu deskriptif untuk menggambarkan keadaan yang berkaitan dengan permasalahan yang diteliti. Hasil penelitian yang tidak dapat dijelaskan secara kuantitatif, dianalisis secara deskriptif agar peneliti dapat memberikan gambaran serta penjelasan atas data hasil penelitian yang diperoleh. Kemudian data di analisis secara kuantitatif menngunakan metode analisis fungsi produksi (AFP) Cobb-Douglas. Adapun Model dan keterangan untuk analisis fungsi produksi sebagaimana berikut:

$$
\mathrm{Y}=\mathrm{b} 0 \times 1^{\mathrm{b} 1} \mathrm{X} 2^{\mathrm{b} 2} \times 3^{\mathrm{b} 3} \mathrm{X} 4^{\mathrm{b} 4} \mathrm{e}^{\mathrm{u}}
$$

b0 merupakan intersep/konstanta; b1..,b4 merupakan elastisitas produksi $(\mathrm{X} 1, \ldots, \mathrm{X} 4)$; merupakan produksi dalam satuan $\mathrm{kg} ; \mathrm{X} 1$ merupakan benih dalam satuan $\mathrm{kg} ; \mathrm{X} 2$ merupakan pupuk dalam satuan $\mathrm{kg} ; \mathrm{X} 3$ merupakan pestisida dalam satuan $\mathrm{kg}$; X4 merupakan tenaga kerja (HOK); e 
merupakan bilangan natural; u merupakan kesalahan.

Agar pendugaan hasil fungsi lebih mudah ditentukan maka fungsi CobbDouglas diubah ke dalam bentuk linier sebagaimana berikut:

$\mathbf{L n Y}=\beta 0+\beta 1 \operatorname{LnX} 1+\beta 2 \operatorname{LnX} 2+\beta 3 \operatorname{LnX} 3$ $+\beta 4 \operatorname{LnX} 4+\mathrm{u}$

Analisis efisiensi dilakukan dengan menggunakan rumus berikut:

NPMx $=$ Px, atau $\frac{\text { NPMx }}{P x}=1$

Penerimaan usahatani dianalisis dengan menggunakan rumus berikut:

$$
\mathrm{TR}=\mathrm{Y} \text {. Py }
$$

Dalam penentuan biaya tetap menggunakan rumus:

$$
\mathrm{FC}=\sum_{i=1}^{n} \mathrm{X} 1 \mathrm{Px} 1 \text { dan Biaya total : }
$$

$\mathrm{TC}=\mathrm{FC}+\mathrm{VC}$

Pendapatan usahatani menggunakan

rumus : $\pi=\mathrm{TR}-\mathrm{TC}$

\section{HASIL DAN PEMBAHASAN}

\section{Faktor yang mempengaruhi produksi tembakau.}

Fungsi produksi ditentukan dengan menggunakan metode analisis regresi linier berganda dengan menggunakan software program SPSS untuk mempermmudah proses analisis

\section{Tembakau dengan sistem jual di pohon}

Berdasarkan analisis regresi linier berganda terhadap lima jenis variabel independen (benih, pupuk, pestisida, tenaga kerja dan intensitas penyiraman) dan produksi usahatani tembakau sebagai variabel dependen didapatkan hasil sebagaimana pada Tabel 1 .
Tabel 1. Hasil Uji Regresi Tembakau dengan Sistem Jual di Pohon

\begin{tabular}{cccc}
\hline Model & $\mathrm{B}$ & $\mathrm{T}$ & Sig. \\
\hline Constant & 6,028 & 5,823 & 0,000 \\
Benih & 0,183 & 2,274 & 0,032 \\
Pupuk & 0,018 & 0,485 & 0,632 \\
Pestisida & $-0,073$ & $-0,934$ & 0,360 \\
Tenaga & 0,342 & 3,260 & 0,003 \\
Kerja & 0,146 & 2,744 & 0,011 \\
Int. & & & \\
Penyiraman & & & \\
$\mathrm{R}^{2}=0,625$ & \\
$\mathrm{~F}_{\text {hitung }}=7,994$. & $\mathrm{F}_{\text {tabel }}=3,90$ (alpha $\left.10 \%\right)$ \\
$\mathrm{t}_{\text {tabel }}=1,699$ (alpha $\left.10 \%\right)$ & \\
Subl
\end{tabular}

Sumber : Data primer diolah (2019)

Dari hasil uji regresi, maka dapat dibentuk menjadi persamaan regresi sebagaimana berikut:

$\mathbf{L N Y}=6,028+0,183 \ln \mathrm{X} 1+0,018 \ln \mathrm{X} 2-$ $0,073 \ln X 3+0,342 \ln \mathrm{X} 4+0,146 \ln \mathrm{X} 5+\mathrm{u}$.

$\mathrm{X} 1=$ benih $(\mathrm{kg})$

$\mathrm{X} 2=$ pupuk $(\mathrm{kg})$

$\mathrm{X} 3$ = pestisida $(\mathrm{kg})$

$\mathrm{X} 4=$ tenaga kerja $(\mathrm{HOK})$

$\mathrm{X} 5=$ intensitas penyiraman $(\mathrm{kali})$

\section{Uji Koefisien Determinasi $\left(R^{2}\right)$}

Nilai $R^{2}$ yang didapat sebesar 0.625 atau $62,5 \%$. Berdasarkan nilai $\mathrm{R}^{2}$ dapat dinyatakan variabel independet memiliki kemampuan untuk memberikan informasi terhadap variabel dependen yang cukup tinggi. Untuk itu variabel dependen dalam hal ini adalah intensitas penyimaran, benih, pupuk, pestisida dan tenaga kerja berpengaruh terhadap produksi usaha tani tembakau sebesar $62,5 \%$ sedangkan 37,5\% yang merupakan sisa prosentase pengaruh dapat diidentifikasi dan dijelaskan oleh faktor lain yang berupa faktor lain dari 5 variabel dalam penelitian karena tiak dapat terukur dalam model secara kuantitatif.

\section{Uji Keragaman (Uji F)}

Uji F dilakukan dengan tujuan untuk mengetahui keberartian dari nilai $\mathrm{R}^{2}$. Berdasarkan uji $\mathrm{F}$ dengan menggunakan 
SPSS, didapatkan nilai $\mathrm{F}_{\text {hitung }}$ sebesar 7,994 dengan nilai sign. Adapun nilai $\mathrm{F}_{\text {tabel }}$ pada tingkat kepercayaan 99\% (alpha $=0,01$ ) untuk df $\mathrm{N} 1=5$ dan df N2 $=24$ sebesar 3,90. Berdasarkan hasil yang didapat maka bisa disimpulkan bahwa nilai $\mathrm{F}_{\text {hitung }}$ sebesar 7,994 lebih besar dari $F_{\text {tabel }}$ yaitu 3,90, sehingga seluruh variabel bebas yang meliputi intensitas penyiraman, benih, pupuk, pestisida dan tenaga kerja memberikan pengaruh terhadap variabel dependen (produksi usahatani tembakau).

\section{Uji t}

Uji $t$ dilakukan dengan tujuan untuk mengetahui adanya pengaruh variabel independen secara parsial terhadap variable dependent. Uji $t$ adalah dengan cara membandingkan nilai thitung dan nilai ttabel, dengan kepercayaan 90\% (alpha = $0.1)$ dan df dengan menggunakan rumus n-1 sebesar 62 dan diperoleh nilai $t_{\text {tabel }}$ sebesar 1,699. Dengan demikian maka hasil analisis regresi variabel independen berpengaruh terhadap variabel dependen dalam hal ini adalah produksi usahatani tembakau sebagaimana data yang telah disajikan pada Tabel 1.

\section{a. Intensitas Penyiraman}

Nilai koefisien regresi pada intensitas penyiraman sebesar 0,146 dan nilai $t_{\text {hitung }}$ sebesar 2,744. $t_{\text {hitung }}$ lebih besar nilainya diandingkan dengan $t_{\text {tabel }}$ yaitu sebesar 2,744 $>1,699$. Nilai koefisien regresi pada faktor independen yang berupa intensitas penyiraman bertanda positif. Nilai $t_{\text {hitung }}$ berdasarkan statistik faktor pada intensitas penyiraman dapat dinyatakan berpengaruh nyata terhadap produksi usaha tani tembakau di Kabupaten Pamekasan.

Pada budidaya tembakau, penyiraman merupakan salah satu proses penting dalam usahatani tembakau. Penyiraman dilakukan setiap hari baik dipagi hari maupun pada sore hari. Penyiraman sangat penting karena memiliki dampak terhadap pertumbuban tanaman dan daun tembakau. Tanaman yang kekurangan air akan mengalami layu pada daun dan daun cepat menguning dan kering yang berdampak pada kualitas tembakau.

Berdasarkan nilai hasil pada koefisien regresi yaitu sebesar 0,146 yang bermakna bahwa peningkatan intensitas penyiraman tanaman tembakau sejumlah $1 \%$ akan mampu meningkatkan produksi dalam usaha tani tembakau sebesar $0,146 \%(0,15 \%)$, Selanjutnya apabila intensitas penyiraman dikurangi sebesar $1 \%$ maka akan terjadi pengurangan hasil produksi sejumlah $0,15 \%$.

\section{b. Benih}

Nilai koefisien regresi adalah 0,183 sedangkan nilai $t_{\text {hitung }}$ adalah 2,274 pada variabel independen benih. Nilai koefisien juga bertanda positif. Berdasarkan perbandingan bahwa nilai thitung lebih besar dibandingkan $t_{\text {tabel }}$ dengan nilai 2,274 > 1,699. Berdasarkan hal tersebut maka secara statistic, dapat dinyatakan bahwa faktor benih berpengaruh nyata terhadap produksi tembakau di Kabupaten Pamekasan.

Maka bedasarkan hasil penelitian dapat dinyatakan bahwa semakin banyak benih yang digunakan pada usaha tani tembakau, semakin tinggi pula produksi usaha tani tembakau. Umumnya pada tataran budidaya tembakau apabila pada proses penyulaman, terdapat tembakau yang bermasalah dalam pertumbuhan yaitu pertumbuhan kurang yang dapat diindikasikan melalui kelayuan pada daun, terserangnya oleh hama dan penyakit bahkan hingga menyebabkan kerdil, dengan demikian maka secara otomatis tembakau yang bermasalah tersebut langsung dicabut. Untuk itu semakin banyak benih yang ditanam, maka sisa tembakau yang ada di lahan semakin banyak pula, sehingga dapat meningkatkan produksi tembakau. Produksi tembakau ditentukan oleh jumlah 
dan ketebalan daun tanaman tembakau, sehingga jika dalam suatu lahan penggunaannya benih optimal akan meningkatan produksi tembakau. Penelitian Sholeh (2012) menunjukkan bahwa pengguaan benih dalam usahatani wortel dapat berpengaruh nyata terhadap produksi.

Berdasarkan pada hasil analisis dalam penelitian didapatkan hasil koefisien regresi yaitu 0,183 . Berdasarkan hal tersebut maka apabila peningkatan penggunaan bibit dilakukan sebanyak 1\%, akan dapat meningkatkan produksi sebesar 0,18. Demikian pula apabila penggunaan bibit diturunkan sebanyak $1 \%$ maka hasil produksi akan mengalami penurunan sejumlah $0,18 \%$.

\section{c. Pupuk}

Nilai koefisien regresi pada variabel indepeden pupuk bertanda positif dan besarannya adalah 0,018 dengan nilai $t_{\text {hitung }}$ 0,485 . Nilai koefisien regresi $\left(t_{\text {hitung }}\right.$ ) apabila dibandingkan dengan $t_{\text {tabel }}$ lebih kecil yaitu dengan nilai $t_{\text {tabel }} 0,485<1,699$. Berdasarkan analisis statistic dengan regresi linier berganda, dapat dinyatakan bahwa faktor pupuk tidak berpengaruh nyata terhadap produksi tembakau di Kabupaten Pamekasan.

Berdasarkan hasil analisis menunjukkan bahwa jumlah penggunaan pupuk yang berbeda memberikan kemungkinan bahwa hasil produksi usaha tani tembakau tetap sama. Lebih lanjut penggunaan pupuk dengan jumlah yang besar belum tentu dapat memberikan hasil produksi usaha tani yang tinggi. Hal tersebut terjadi dikarenakan dalam pemberian pupuk antar petani berbeda-beda baik dari segi dosis maupun jenis.

Petani lebih mengutamakan penggunaan pupuk dari percobaan petani lain yang berhasil padahal memiliki luas lahan dan pertumbuhan tanaman yang berbeda, hal yang demikian memberikan dampak pada hasil produksi usaha tani tembakau. Selain itu kejadian di lokasi penelitian, beberapa petani sengaja menekan biaya untuk pemupukan, sehingga lebih irit dalam penggunaan pupuk pada budiaya tembakau. Penggunaan pupuk yang tepat waktu dan sesuai takaran/dosis dapat berdampak pada peningkatan hasil produksi (Suwalan et al., 2004).

d. Pestisida

Nilai koefisien regresi pada variabel independen pestisida bertanda negative. Besaran nilai koefisisen regresi adalah 0,073 dan nilai $\mathrm{t}_{\text {hitung }} 0,934 . \mathrm{t}_{\text {hitung }}$ berdasarkan nilai koefisien lebih kecil dari pada $t_{\text {tabel }}(0.934>$ 1,699).

Berdasarkan hasil statistic, variabel independen pestisida tidak berpengaruh nyata terhadap variabel dependen yng berupa produksi usaha tani tembakau di Kabupaten Pamekasan. Dengan demikian hasil analisis regresi linier menunjukkan bahwa penggunaan pestisida dalam penanganan hama penyakit tanaman tembakau antar petani berbeda-beda.

Penggunaan yang berbeda disebabkan karena dalam usaha tani tembakau yang utama adalah penyiangan agar jika terkena hama tidak menyebar ke tanaman lain. Cara tradisional dengan cara mengambil hama langsung lebih efektif dan lebih cepat dibandingkan dengan penyemprotan menggunakan pestisida. Dalam usahatani tembakau, penggunaan pestisida tidak terlalu banyak diaplikasikan. Petani lebih mengutamakan dengan cara melakukan penyiangan disetiap tanaman tembakau karena melakukan kontak langsung dengan hama tembakau.

\section{e. Tenaga kerja}

Nilai koefisien regresi pada variabel independen tenaga kerja bertanda positif dengan besaran nilai 0,342. Adapun nilai 
$\mathrm{t}_{\text {hitung }} 3,360$ sehingga dapat dikatakan bahwa nilai $t_{\text {hitung }}$ lebih besar dari pada $t_{\text {tabel }}(3,360>$ 1,699). Berdasarkan nilai statistik faktor tenaga kerja berpengaruh nyata terhadap produksi tembakau di wilayah penelitian. Dalam usaha tani tembakau, memerlukan tenaga kerja pada proses pengolahan, penanaman, pemupukan, penjarangan dan penyiangan, penyiraman sampai dengan panen. Semua perlakuan tersebut berpengaruh terhadap produksi dalam usaha tani tembakau. Tenaga kerja yang kurang memadai pada proses produksi usaha tani menjadi terhambat sehingga hasilnya kurang maksimal. Terhambatnya jalannya produksi karena tenaga kerja berdampak pada menurunnya hasil produksi tembakau.

Proses yang banyak membutuhkan tenaga kerja yaitu pada proses penyiraman karena tanaman harus disiram setiap hari sampai maksimal 3 bulan. Jika dalam 1 hari minimal ada 2 orang yang menyiram tanaman dengan estimasi tanaman tembakau sebanyak 8.000 pohom, maka jika selama 3 bulan akan membutuhkan minimal 180 HOK.

Kebutuhan tersebut hanya dalam proses penyiraman. Maka dari itu ketersediaan tenaga kerja sangat penting dalam usahatani tembakau.Berdasarkan hasil koefisien regresi sebesar 0,342 maka dapat dinyatakan bahwa peningkatan jumlah tenaga kerja sebesar $1 \%$ akan meningkatkan produksi tembakau sebesar $0,34 \%$. Demikian pula jika penggunaan tenaga kerja diturunkan sejumlah $1 \%$ akan menurunkan produksi tembakau sebesar $0,34 \%$.

\section{Tembakau dengan penanganan pasca panen}

Hasil uji regresi dengan terhadap variabel independen yang diantaranya intensitas penyiraman, benih, pupuk, pestisida dan tenaga kerja terhadap variabel dependen yaitu produksi usaha tani tembakau dapat dilihat pada Tabel 2.

Tabel 2. Hasil Uji Regresi Tembakau dengan Penanganan Pasca Panen

\begin{tabular}{lccc}
\hline \multicolumn{1}{c}{ Model } & B & T & Sig. \\
\hline Constant & 5,090 & 5,391 & 0,000 \\
Benih & 0,196 & 2,035 & 0,053 \\
Pupuk & 0,016 & 1,023 & 0,316 \\
Pestisida & $-0,017$ & $-0,315$ & 0,756 \\
Tenaga Kerja & 0,402 & 3,830 & 0,001 \\
Int. & 0,208 & 2,432 & 0,023 \\
Penyiraman & & \\
\hline $\mathrm{R}^{2}=0,616$ & \\
$\mathrm{~F}_{\text {hitung }}=7,711$. & $\mathrm{F}_{\text {tabel }}=3,90$ (alpha 10\%) \\
$\mathrm{t}_{\text {tabel }}=1,699$ (alpha 10\%) \\
Sumber : Data primer diolah (2019)
\end{tabular}

Berdasarkan hasil uji regresi linier berganda maka, dapat dibuat dalam bentuk persamaan regresi sebagai berikut:

$\mathbf{L N Y}=6,028+0,183 \ln \mathrm{X} 1+0,018 \ln \mathrm{X} 2-$ $0,073 \ln X 3+0,342 \ln X 4+0,146 \ln X 5+u$. $\mathrm{X} 1=$ benih $(\mathrm{kg})$

$\mathrm{X} 2=\operatorname{pupuk}(\mathrm{kg})$

$\mathrm{X} 3$ = pestisida $(\mathrm{kg})$

$\mathrm{X} 4=$ tenaga kerja $(\mathrm{HOK})$

$\mathrm{X} 5=$ intensitas penyiraman (kali)

\section{Uji Nilai Koefisien Determinasi $\left(\mathrm{R}^{2}\right)$}

Dalam penelitian, didapatkan nilai $\mathrm{R}^{2}$ sebesar 0.616 atau dapat dinyatakan dengan $61,6 \%$. Berdasarkan hal tersebut maka dapat dikatakan bahwa kemampuan variabel independen dalam memberikan informasi terhadap variabel dependen cukup tinggi. Berdasarkan hal tersebut maka dapat dinyatakan bahwa variabel independen dalam hal ini adalah intensitas penyiraman, benih, pupuk, pestisida dan tenaga kerja memiliki pengaruh sebesar $62,5 \%$ terhadap peningkatan atau penurunan produksi usahatani tembakau. Sisanya yang berjumlah $37,5 \%$ dapat dijelaskan oleh faktor lain yang tidak termasuk dalam model karena tidak dapat di ukur dalam penelitian secara kuantitatif. 


\section{Uji Keragaman $(F)$}

Uji $F$ dilakukan dengan tujuan mengetahui bagaimna keberartian dari nilai R2. Berdasarkan hasil uji keragaman dengan bantuan analisis menggunakan software SPSS, didapatkan $\mathrm{F}_{\text {hitung }}$ dengan nilai sebesar 7,711 pada nilai signifikansinya 0,000 . Adapun nilai $\mathrm{F}_{\text {tabel }}$ pada tingkat kepercayaan 99\% atau alpha 0,01 dengan df N1 adalah 5 dan df N2 adalah 24 yaitu sebesar 3,90.

Berdasarkan perbandingan antara $\mathrm{F}_{\text {hitung }}$ dan $\mathrm{F}_{\text {tabel }}$ maka dapat dinyatakan bahwa $F_{\text {hitung }}(7,711)$ lebih besar dari $F_{\text {tabel }}$ $(3,90)$, sehingga seluruh variabel independen pada penelitian yang berupa intensitas penyiraman, benih, pupuk, pestisida dan tenaga kerja mampu memberikan pengaruh pada variabel dependen yang dalam hal ini adalah produksi usahatani tembakau.

\section{Uji t}

Hasil analisis dilihat dari nilai $t_{\text {hitung }}$ dibandingkan dengan nilai $t_{\text {tabel. }}$ Maka faktorfaktor yang mempengaruhi produksi tembakau dilihat pada Tabel 2. yaitu penggunaan benih, tenaga kerja dan intensitas penanaman dengan tingkat kesalahan $10 \%$. Hal ini menunjukkan bahwa faktor-faktor yang berpengaruh terhadap produksi tembakau baik dengan sistem jual di pohon maupun dengan penangan pasca panen sama yaitu faktor benih, tenaga kerja dan inensitas penyiraman. Perbedaannya

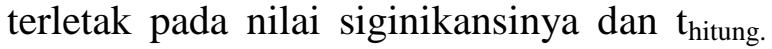
Sedangkan faktor penggunaan pestisida sama-sama memiliki nilai koefisien yang negative, artinya penggunaan pestisida musti dikurangi.

\section{Efisiensi faktor-faktor produksi terhadap usahatani tembakau.}

Efisiensi yang dianalisis dalam penelitian ini yaitu efisiensi alokatif dengan cara menentukan nilai rasio NPM dari faktor produksi dengan nilai/harga dari masing- masing faktor dalam produksi (NPMx/Px). Analisis efisiensi alokatif dihitung dengan cara menentukan nilai koefisien regresi pada faktor-faktor produksi dan berasal dari fungsi produksi Cobb-Douglas. Efisiensi alokatif dari fungsi produksi Cobb-Douglas didapatkan dari hasil analisis menggunakan software SPSS.

Berdasarkan hasil analisis dapat dinyatakan bahwa variabel bebas dari penelitian, tidak seluruhnya berpengaruh secara nyata terhadap produksi usahatani tembakau. Adapun variabel bebas yang berpengaruh secara nyata terdiri dari tiga variabel bebas yang berpengaruh nyata yaitu variabel bebas yang berupa beinh, tenaga kerja. dan intensitas penyiraman. Hasil analisis terhadap efisiensi alokatif sebagaimana disajikan pada Tabel 3 dan 4 .

Tabel 3. Analisis Efisiensi Alokatif Usahatani Tembakau dengan Sistem Jual di Pohon di Kecamatan Pademawu Kab. Pamekasan

\begin{tabular}{ccccc}
\hline Variabel & bix & Y & X & NPMx/Px \\
\hline Benih & 0,183 & 8138.40 & & \\
& & & 7368.00 & 0.61 \\
Tk & 0,342 & 8138.40 & 359.70 & 3.10 \\
Penyiraman & 0,146 & 8138.40 & 36.66 & 9.41
\end{tabular}

Sumber: Data primer diolah (2019)

Tabel 4. Analisis Efisiensi Alokatif Usahatani Tembakau Sistem Penanganan Pasca Panen di Kecamatan Pademawu

\begin{tabular}{ccccc}
\hline Variabel & bix & Y & X & NPMx/Px \\
\hline Benih & 0,196 & 8932.40 & & \\
& & & 7368.00 & 0.95 \\
Tk & 0,402 & 8932.40 & 398.50 & 4.81 \\
Penyiraman & 0,208 & 8932.40 & 47.23 & 10.89 \\
\hline
\end{tabular}


Berdasarkan hasil analisis didapatkan NPMx/Px penggunaan benih sebesar 0,61 (untuk sistem jual di pohon) dan 0,95 (untuk pengananan pasca panen). Nilai dari hasil analisis efisiensi yang didapatkan kurang dari 1, sehingga penggunaan benih di daerah penelitian tidak efisien. Hal ini menunjukkan bahwa penggunaan benih di daerah penelitian baik yang melakukan penanganan pasca panen maupun dengan sistem jual perlu dikurangi penggunannya. Seharusnya tiap lubang tanam ditanami 1 tanaman benih tembakau agar pertumbuhannya maksimal dan tidak ada persaingan antar tanaman akan tetapi banyak petani yang menggunaan 2-3 benih tanaman tembakau dengan alasan agar jika ada tanaman yang pertumbuhannya tidak maksimal langsung dicabut dan tidak usah menyulam.

Perbandingan antara petani yang melakukan sistem penanganan pasca panen dan yang menjual di pohon lebih efisien yang melakukan penanganan pasca panen dengan nilai NPMx/Px dengan besaran nilai 0,95. Dengan demikian hasil berdasarkan hasil NPMx/Px menunjukkan bahwa secara efisiensi alokatif, perlakuan petani yang melakukan penanganan pasca panen lebih efisien dibandingkan yang sistem jual di pohon.

\section{Efisiensi Alokatif Variabel Tenaga Kerja}

Berdasarkan hasil analisis didapatkan NPMx/Px penggunaan tenaga kerja dengan nilai sebesar 3,10 pada sistem usahatani jual pohon dan penggunaan tenaga kerja dengan besaran nilai 4,81 (untuk pengananan pasca panen) dimana nilai-nilai tersebut lebih besar dari 1. Jika nilai lebih dari 1 maka apat dinyatakan bahwa penggunaan tenaga kerja di wilayah penelitian yang dilakukan belum mencapai titik efisien. Untuk dapat mengoptimalkan penggunaan tenaga kerja maka perlu ditambahkan tenaga kerja, sehingga produksi dan pendapatan dalam usaha tani tembakau dapat ditingkatkan pula.

Di daerah penelititan yang membutuhkan tenaga kerja paling banyak yaitu pada proses penyiraman dan penanganan pasca panen. Penyiraman merupakan proses penting karena apabila dalam 3 hari tanaman tembakau yang baru ditanam tidak disiram maka tanaman tersebut akan layu dan cenderung mati. Dari hasil perhitungan NPMx/Px, petani yang menjual tanaman tembakau dengan sistem jual di pohon lebih efisien dibandingkan dengan yang sistem penanganan pasca panen. Petani yang melakukan penanganan pasca panen lebih banyak membutuhkan tenaga kerja karena mereka akan terus melakukan penyiraman sampai tanaman tembakau tersebut dipanen. Sedangkan petani yang menjual daun tembakau di pohon cenderung tidak melakukan penyiraman setelah tanaman tembakaunya sudah laku terjual meskipun belum dipanen.

Tembakau yang dilakukan penanganan pasca panen juga membutuhkan tenaga kerja saat melakukan proses sortir, penggulungan, pencacahan, penjemuran dan pengepakan. Hal ini menunjukkan bahwa penggunaan tenaga kerja dalam usahatani tembakau perlu ditambah agar produksinya optimal.

\section{Efisiensi Alokatif Variabel Intensitas Penyiraman}

Hasil analisis efisiensi alokatif didapatkan nilai NPMx/Px dari variabel intensitas penyiraman sebesar 9,41 (untuk sistem jual di pohon) dan 10.89 (untuk pengananan pasca panen). Nilai dari hasil analisis efisiensi alokatif lebih dari 1, dengan demikian maka dapat dinyatakan bahwa efisiensi alokatif dari variabel intensitas penyiraman di lokasi penelitian masih tidak efisien.

Upaya yang dapat dilakukan agar nilai eisiensi alokatif dapat optimal, diperlukan 
penambahan pada intensitas penyiraman, sehingga dengan demikian produksi dan pendapatankan dapat ditingkatkan. Dalam hal ini artinya petani tetap menyiram tanaman tembakaunya meskipun sudah dipanen. Mayoritas petani yang menjual tembakau di pohon tidak melakukan penyiraman terhadap tembakau karena sudah laku terjual, sehingga daun tanaman tembakau banyak yang layu atau kering. Petani seharusnya tetap melakukan penyiraman sampai daun tembakau dipanen terakhir. Rata-rata daun tembakau dipanen sampai 2-3 kali panen. Hal tersebut dilakukan agar daun tembakau yang hijau sampai menguning karena berdampak pada kualitas daun tembakau.

\section{KESIMPULAN}

1. Faktor yang dapat mempengaruhi secara nyata dan signifikan dalam produksi usahatani tembakau baik sistem jual di pohon maupun dengan sistem penanganan pasca panen yaitu penggunaan benih, tenaga kerja dan intensitas penyiraman, sedangkan penggunaan pestisida berpengaruh negatif.

2. Penggunaan benih pada usahatani tembakau baik dengan sistem jual pohon maupun dengan sistem penanganan pasca panen tidak efisien, maka dari itu perlu pengurangan penggunaan benih, sedangkan untuk penggunaan tenaga kerja dan intensitas penyiraman masih belum efisien sehingga perlu penambahan tenaga kerja dan juga intensitas penyiraman khususnya bagi petani yang melakukan penanganan pasca panen tembakau.

\section{DAFTAR PUSTAKA}

Direktorat Jenderal Perkebunan 2016. Statistik Perkebunan Indonesia, 20152017. Tembakau Tobacco(Statistik
Perkebunan

Indonesia

KomoditasTembakau

2015-2017).

Sekretariat Jederal Perkebunan.

Direktorat Jenderal Perkebunan.

Kementrian Pertanian.

Direktorat Jenderal Perkebunan 2012.

Pedoman Penangan Pasca Panen

Tembakau. Direktorat Pascapanen Dan

Pembinaan UsahaDirektorat Jenderal

PerkebunanKementerian Pertanian.

Makeham J.P dan Malcolm R.L. 1990.

Manajemen Usahatani Daerah Tropis.

Bogor.

Mubyarto. 1989. Pengantar Ekonomi

Pertanian. PT Pustaka LP3ES

Indonesia. Jakarta.

Nicholson, Walter. 1994. Teori Ekonomi Mikro. PT RajaGrafindo Persada. Jakarta

Rahim, ABD dan Diah Retno Dwi Hastuti. 2008. Ekonomika Pertanian

(Pengantar, Teori dan Kasus). Penebar Swadaya. Jakarta.

Shinta, Agustina. 2005. Diklat Ilmu Usahatani. Fakultas Pertanian Universitas Brawijaya. Malang.

Sholeh dkk, 2012. Analisis Efisiensi Alokatif Penggunaan Faktor-Faktor Produksi Usahatani Wortel (Daucus Carota L) Di Kecamatan Bumiaji Kota Batu.

Soekardono, dkk. 2005. Teori Ekonomi Makro Pendekatan Grafis dan Matematis. Pondok Edukasi. Malang. Soekartawi. 1990. Teori Ekonomi Produksi Dengan Pokok Bahasan Analisis Fungsi Cobb-Douglas. RajaGrafindo Persada. Jakarta. 2002. Analisis Usaha tani. Universitas Indonesia. Jakarta 